\title{
PERAN PARA SULTAN DALAM PENYEBARAN ISLAM DI GORONTALO
}

\author{
Oleh: Sirajuddin Ismail
}

\begin{abstract}
This study aims to describe the role of royales in Former Gorontalo Kingdoms. This study was conducted in Gorontalo. Data was collected using interview and observation. Interview was conducted with local Islamic Historician.

This Study Indicates that Islamic come into Gorontalo in several ways, such are marriage, education, and politic. The role of Former Gorontalo Royales was very important to Islamic diaspora in Gorontalo society. The Kings that have main role are Sultan Amai, Sultan Matolodulakiki, and Sultan Jogugu Eyato. The kings succesed to integrate Islamic value into local tradition.
\end{abstract}

Keyword: Islamitation, role of Royales.

\section{A. Pendahuluan}

I

ndonesia yang terdiri atas beribu pulau didiami oleh beribu etnik dan memiliki latar belakang sejarah yang beragam dan di setiap daerah dijumpai terjadinya Islamisasi yang merupakanbagian sejarah lokal danbagi setiap etnik memiliki sejarah tersendiri yang merupakan pusat kosmos. Maka peneltian tentang proses Islamisasi tidak hanya diperlukan oleh orang yang berasal dari daerah tersebut, tetapi diperlukan pula oleh orang lain. Disamping akan dipelajari juga dijadikan data komparatif bagi penelitian sejarah secara nasinal, solidaritas bangsa dan umat Islam dan biasa berahir dalam suasana kerukunan.

Mengenal Islamisasi lokal berarti memperluas pengetahuan tentang latar belakang sejarah muslim secara nasional, namun kedatangan Islam di suatu daerah di Indonesia tidak bersamaan, sehingga memberikan dimensi masing- 
masing sesuai dengan situasi dan kondisi daerah. Penulisan Islamsasi secara utuh dan komfrehensif menjadi sangat penting karena substansi sejarah bukan hanya peristiwa belaka, melainkan penafsiran tentang peristiwa dan hubungannya dengan berbagai faktor serta memberikan dinamika di dalam situasi dan kondisi tertentu.

Penulisan sejarah merupakan sumbangan bagi perkembangan studi Islamsasi dan dijadikan rujukan untuk menumbuhkan kesadaran umat dengan belajar dari pengalaman umat terdahulu dalam mengarugi bahtera kehidupan dan menjadi kultur di masa depan. Oleh karena itu manusia akan mengenal jati dirinya sebagai umat Islam dalam perspektif sejarah, karena Islam mengajarkan umatnya tidak menafikan sejarah umat terdahulu untuk menjadi i'tibar bagi mereka dalam menjalani kehidupan di masa depan.

Islamisasi di Gorontalo di samping mengacu pada data lapangan, juga mengacu pada tulisan Prof.Drs.H.Ibrahim Polontalo, antara lain (makalah) yang berjudul, Sejarah perkembangan Islam sebagai Sumber Budaya dan peradaban Pada Kerajaan Gorontalo Sejak Abad ke XVI.2) dan naskah tulisan tangan dengan menggunakan ejaan lama, ditulis oleh Br. Yassin,Djahiroen dan Hasan B.S Kaloehoe. Judul, Catatan Sedjarah Singkat Kerajaan Gorontalo doelaewu Lumo Lopahalaa. Oleh karena itu maka tulisan ini menampilkan peranan raja Amai dalam proses Islamisasi di Kerajaan Gorontalo.

Masalah pokok dalam penilitian, adalah sultan Amai di Gorontalo (Studi Tentang Islamisasi) dan dari masalah pokok tersebut secara rinci dirumuskan masalah penelitian, yaitu Apa, bagaimana raja Amai dan Islamisasi di Gorontalo. Bagaimana hubungannya dengan Islamisasi di Indonesia.

Tujuan dan Kegunaan Penelitian, secara teknis tujuan penelitian ini terbagi atas dua bagian, yaitu 1) tujuan Umum, Menggambarkan tentang peranan raja Amai, dan Islamisasi di Kerajaan Gorontalo, 2) tujuan khusus, menggambarkan apa dan bagaimana peranan raja Amai dalam hubungannya dengan Islamisasi di kerajaan Gorontalo dan juga menggambarkan tentang hubungan Islamisasi di Gorontalo dengan daerah lain di Indonesia.

Kegunaan Penelitian, drfiarapkan sebagai masukan bagi penentu kebijakan dalam rangka perencanaan pembangunan keagamaan, terutama tentang Islam di Gorontalo karena Islamisasi di Gorontalo memiliki nilai luhur dan bersejarah mengantar masyarakat Gorontalo menjadi masyarakat idial dalam hidup dan kehidupannya. 


\section{Landasan Teori}

Islamisasi hingga kini dimaknai secara beragam oleh setiap orang sesuai dengan interprestasinya masing-masing dan suatu hal yang wajar dalam suatu ilmu pengetahuan. Melalui teori komunitas, Islamisasi adalah suatu proses yang tidak pernah berhenti, yakni sejak masuknya Islam pertama, penerimaan dan penyebarannya lebih lanjut hingga kini. (Ricklefs, 1981 : 6) Teori periodik Noorduyn, membagi proses Islamisasi pada tiga fase, yaitu 1) de komsit (datang) dipengaruhi oleh motif ekonomi. 2) Receptie (Penerimaan) didorong oleh motivasi agama. 3). Vitbreiding (pengembangan) di dorong oleh motivasi politik. (1987:10)

Islamisasi dalam pengertian penerima Islam dapat diartikan sebagai konvensi dan perubahan sosial budaya, konvensi adalah perpindahan agama atau kepercayaan yang dianut sebelumnya kepada Islam. (Azra, 1992:21) Sedangkan Islamisasi dalam pengertian jika dihubungkan dengan perubahan sosial budaya, yaitu perubahan yang terjadi secara adaptasi atau penyesuaian secara bertahap dari budaya para penyebar Islam kepada budaya Islam. Muballig Islam tidak melakukan perubahan terhadap pranata sosial budaya yang telah ada dan sebaliknya mereka memberikan nilai Islam pada pranata lama sehingga pada gilirannya melahirkan pranata yang baru. (Sewang, $2005: 6$ )

Jalur Islamisasi menurut Tjandrasasmita, yaitu jalur perdagangan (jalur pada tahap permulaan), perwakilan, pendidikan (Tasauf), kesenian (asimilasi) melalui kesenian seperti sastera (hikayat, babad, seni ukir, seni bangunan) dan politik.

Peranan penguasa dalam proses Islamisasi sangat menentukan. Peranan raja dalam Islamisasi sangat. penting dan statement ini menunjukkan, bahwa jika Gubernur, para bangsawan dan para bangsawan menerima agama baru, rakyat akan siap mengikuti, karena dalam adat memiliki tingkat yang berbeda, raja atau sultan mereka dipandang sebagai wakil Tuhan di Dunia. (Tjandrasasmita, 1986:24)

Konsep tersebut menunjukkan bahwa proses Islamisasi melalui fase kedatangan, penerimaan dan pengembangan. Selanjutnya Islam disosialisasikan melalui beberapa jalur, yaitu melalui jalur perdangangan, perkawinan, tasauf ( pendidikan non formal), kesenian dan politik. Ternyata metode yang berhasil adalah metode yang melalui jalur perkawinian dan politik ( raja), artinnya melakukan kawin mawin dengan keluarga penguasa atau raja dan mereka dianggap oleh masyarakatnnya adalah wakil Tuhan di dunia. 
Sirajuddin Ismail

Peranan raja dalam proses Islamisasi dikategorikan sebagai legitimasi dan merupakan kunci keberhasilan bagi para muballig karena apabila Islam memperoleh legistimasi dari raja menganut Islam dan memproklamirkan Islam sebagai agama kerajaan maka otomatis masyarakat menerima dengan sami ' $n a$ ' wa atho 'na karena raja adalah wakil Tuhan di dunia.

\section{B. Sekilas Tentang Masuknya Islam di Sulawesi Utara}

Islam masuk di Indonesia berasal dari jazirah Arab, Persia dan India. Ada pendapat yang mengungkapkan, bahwa belum cukup 30 tahun keberadaan Islam di Arab, utusan dari Arab telah sampai ke Cina $(651 \mathrm{M})$ dan ada yang mengatakan 15 Juli 622 M (29 H), yaitu pada tahun-tahun pertama Hijriyah. (Abdullah Puar, 1984:15)

Muballig Arab ke Cina melalui laut antara lain melalui Selat Malaka dan dalam safari ke daratan Cina mereka pernah singgah di Ujung Utara Pantai Sumatera untuk istirahat, menambah persiapan dan menunggu cuaca baik untuk berlayar. Bukti sejarah menunjukan, bahwa pada tahun $674 \mathrm{M}$, di Pantai Utara Aceh telah ditemui orang Arab Muslim yang melakukan perniagaan, bahkan di tempat tersebut menurut Amdullah Puar, bahwa pada tahun itu terjadi pristiwa bersejarah mengenai Raja Tashi dan Ratu Sima dari kerejaaan Holing, Raja Tashi berencana melakukan penyerangan terhadap kerajaan Holing, tetapi diperoleh informasi, bahwa kerajaan Holing adalah kerajaan yang makmur. Untuk memproleh kepastian informasi tersebut maka raja Tashi menitahkan seseorang untuk meletakan sebatang emas di jalanan yang biasa dijalani orang berlalu lalang, ternyata selama tiga tahun keberadaan emas batangan di jalan tesebut dan tidak pernah ada orang yang pungut (ambil) atau pindahkan pada tempatnya.

Pada suatu ketika Putera Mahakota kerajaan Holing lewat dan memungut emas tersebut dan setelah ketahuan oleh Ratu maka Putera Mahakota di tangkap dan dilakukan hukuman (bunuh) sebagai imbalan atas prilaku tercelanya (mengambil emas) yang tidak diketahui pemiliknya, tetapi atas permohonan para menterinya maka hanya diberlakukan keringanan hukuman dengan hanya hukuman potong jari terhadapnya. Hal ini menunjukan, bahwa begitu makmurnya masyarakat kerajaan Holing sehingga barang berharga apapun yang mereka temukan (tidak diketahu pemiliknya) mereka tidak akan mengganggunya.

Setelah mengetahui kehebatan, keadilan dan kemakmuran kerajaan Holing maka rencana penyerangan terhadap kerajaan ini tinggal suatu wacana, artinya 
kerajaan Tashi kalah sebelum berperang. Riwayat cina menganggap Tashi adalah Arab karena sebelum Cina menganut agama Islam di Tashi telah tinggal orang Arab Muslim.

Peristiwa Ratu Sima terjadi 42 tahun setelah wafat Nabi Muhamad SAW (632 M), maka jelas bahwa orang Arab Muslim berdomisili di pantai Utara Sumatera (Aceh), Hal itu menunjukan, bahwa Islam masuk di daerah Aceh pada abad pertama Hijriyah. Pendapat tersebut didukung oleh orientalis Barat, seperti Schlegel, Tibbest, Mills dan Arnol dengan menyatakan, bahwa kebenaran Islam sudah mencapai Aceh pada abad pertama Hijriyah. (lihat Abdullah Puar: 18)

Konsep tersebut menunjukan, bahwa banyak pakar sejarah termasuk orintalis Barat sepakat bahwa Agama Islam masuk di Aceh pada abad pertama Hijriyah. Secara universal disepakati dan digambarkan bahwa Islam masuk di Aceh pada abad pertama Hijiriyah dan siapa, kapan dan di daerah mana di Aceh yang pertama menerima Islam masih memerlukan penelitian dan tugas peneliti kedepan yang meneliti tentang masuknya Islam di suatu daerah di Indonesia.

Islam masuk ke Minahasa pada akhir abad $18 \mathrm{M}$, yang dibawa oleh pejuang nasional dari Jawa, sumatera dan Kalimantan, yaitu tahun 1790 M, Tubagus Buang, Penghulu Abusalam, Mas Jebek Mukati, Abdullah Rasyid, Abdulwahid, Abdul Haji dan Abdul Rais (Serang Banten) tahun 1925 M. Rombongan pangeran Diponegoro yang berjumlah 63 orang laki-laki, antara lain Tumenggung Reksonegoro, Tumenggung Ses Pajang, Tumenggung Sasarmayang dan Kyai Mojo.Tahun 1826 M, rombongan SultanNajamuddin II dan pengirhgnya Sayid Abdullah Assagaf. Tahun 1841 M. Rombongan Imam Bonjol dengan rombongan yang sangat banyak tiba di Minahasa, Imam Bonjol wafat di kampung Lotak 6 Nopember 1864 M. Tahun 1885 M. Rombongan Perbatasari dari Banjarmasin.Tahun 1805 M. rombongan dari Padang antara lain SiNamin gelar Malim Muda, Si Gorak gelar panjang, Haji Jamil gelar Sinan Tujuh dan Haji Abdul Halim. Tahun 1859 M. Rombongan dari Aceh (pengikut Tengku Umar), antara lain Tengku Mahmud. Tahun 1890 M. rombongan pemberontak dari Cilegon Banten, antara lain Haji Jaafar, Kasim Maksum dan Tawil Kyai Haji Arsyad.

Perlu dikemukakan bahwa pengaruh para pejuang dan muballig yang dibuang oleh penjajah Belanda di Minahasa Sulawesi Uatara, tidak pernah disebut-sebut dalam proses Islamisasi di Bolaang Mangondow, yang mereka kenal adalah seorang ulama yang didatangkan oleh Belanda ke-Bolaang 
Sirajuddin Ismail

Mangondow atas permintaan raja Yacobus Samuel Manoppo (Sultan Yacobus). Muballig (ulama) Abdul latif Raziek Mekki dari Mekah yang kebetulan bermazhab Syafi'i.

\section{Islamisasi di Gorontalo}

Cikal bakal masuk Islam di Gorontalo tidak terlepas dari masalah kerajaan Gorontalo. Gorontalo masa lalu adalah salah satu kerajaan yang terdapat di pulau Sulawesi. Gorontalo, pada awalnya berupa lautan dan daratan yang nampak hanya puncak gunung Tinongkabila dan puncak gunung Boliyohuto, tetapi lama kelamaan akhirnya menjadi hamparan daratan yang luas dan yang tersisa berupa genangan air, yaitu sebuah danau yang dikenal dengan danau Limboto.

Dinamika kehidupan manusia selalu mengalami perubahan berupa sistem yang mengatur kehidupan itu, antara lain manusia membentuk suatu sistem pemerintahan yang berbentuk monarchi (kerajaan) dan kerajaan tertua di Gorontalo, adalah kerajaan Wada yang dikenal juga dengan sebutan kerajaan Padenyo yang diperintah oleh seorang raja bernama Ihomolangi, yaitu anak dari putrid Bulaidaa garis keturunan raja Mooduto. Raja Ihomolangi memperoleh keturunan Ikihudu (laki-laki) yang dikenal dengan nama Wadipalapa dari perkawinan dengan putrid Rawe.

Kerajaan Gorontalo adalah suatu kerjaan yang terbentuk atas persekutuan 17 kerajaan lokal yang di sebut Linula, yaitu 1) Ihungina, 2). Lupoyo, 3). Bilinggata, 4) Wuwabu, 5). Biawu, 6). Padengo, 7). Ihuangobitu Alowala, 8). Tapa, 9). Lawwonu, 10). Toto, 11). Dumati, 12). Ilotide, 13) Pandungo, 14). Panggulo, 15). Ihuayabatu Alojihi, 16). Tumboo dan 17). Iholondalangi.

Persekutuan kerajaan tersebut dimotori oleh Iholondalangi (raja kerajaan Padengo) karena raja ini raja yang paling berpengaruh di antara ke-17 kerajaan yang bersekutu (Linula) tetapi masih sebatas wacana, tetapi baginda telah meletakan potensi persekutuan di antara multi kerajaan tersebut. Sepeninggal baginda digantikan oleh putranya Ilahudu (Wadipalapa) dan Wadipalapa melanjutkan dan mewujudkan cita-cita baginda ayahandanya mempersatukan 17 kerajaan (Linula), maka pada tahun 1385 M. Terbentuk Kerajaan Gorontalo (Hulondalangi) dan berpusat di Iholawa. Pusat kerajaan selalu berpindahpindah sesuai dengan situasi dan kondisi masyarakat pada masanya, yaitu dari Iholawa berpindah ke-Dongingi kemudian ke-Biawu.

Kerajaan Gorontalo mencapai kemajuan pada masa pemerintahan raja Ilahudu, Ulololi hasil perkawinannya dengan putri laiyo Lembanggo dari Ulololi 
lahir Ntihedu (putri), Ntihedu melahirkan Dedu (putra) dan darinya melahirkan Amai sebagai raja kerajaan Gorontalo yang pertama menerima agama Islam dan sebagai cikal bakal masuk Islam di Gorontalo. (Yassin, Br, tt: 14)

Islamisasi di kerajaan Gorontalo tidak terlepas dari peranan Raja Amai salah seorang pewaris Ilahudu sebagai raja Gorontalo pertama yang mengantar kerajaan Gorontalo mencapai masa keemasan. Ketika melakukan kunjungan kerajaan sebagai seorang raja (kenegaraan) di kerajaan Tamalate Tomini, melakukan pertemuan dengan Bonenato Raja Gumucala Palasa membicarakan/ menawarkan agar masyarakat kerajaan Tamalate Tomini untuk melakukan transmigrasi ke-Gorontalo untuk melakukan pembukaan lahan pertanian dan perkebunan di Gorontalo dan pada perteman ini Raja Amai bertemu dan jatuh cinta pada Awutango putri Bonenato (Raja Muslim, sultan), akhirnya berlanjut raja Amai melamar putri tersebut dan diterima dengan dua pensyaratan, yaitu 1) Raja Amai harus menganut Islam dan akan mengembangkan Islam di daerahnya (Gorontalo), 2) seluruh rakyat Gorontalo wajib menganut Islam. Semua pensyaratan tersebut diterima oleh raja Amai dan dilanjutkan dengan pembaeatan dan peresmian mempersunting (menikahi) putri Awutango, dengan demikian Raja Amai resmi menjadi seorang Muslim dan menantu Raja Bonenato dari kerajaan Tamalate Tomini.

Pembaeatan dan pernikahan raja Amai dengan permaisurinya putri Awutango berlangsung di Palasa Tamalate Tomini pada tahun $1525 \mathrm{M}$, disaksikan oleh para raja di Tamalate Tomini, antara lain raja Sahibullah yang bertindak sebagai naib dalam perkawinan ini dan hasil pernikahan ini lahir seorang putri diberi nama Putri Matolodidakiki. Setelah berlangsungnya proses perkawinannya Raja Amai membawa permaisurinya ke-Gorontalo didampingi oleh kedelapan (8) raja dengan pengawalan ekstra ketat. Keikutsertaan kedelapan raja ini bertujuan untuk pengamanan bagi baginda Raja Amai dengan permaisurinya dalam perjalan dan menjadi pengamanan di Gorontalo dalam melaksanakan kesepakatan yang diikrarkan raja Amai sebagai pensyaratan dalam mempersunting putri Awutango.

Semua raja yang mendamingi raja Amai dan permaisurinya menetap di kerajaan Gorontalo untuk membantu Sultan Amai dalam melaksanakan pemerintahannya termasuk merancang adat dipadukan dengan sara' yang disepakati di kerajaan Tamalate Tomini antara mertuan dan menantunya. Kedelapan raja tersebut, adalah raja tamalate, raja Limboto, raja Siendeng, raja Holangata, raja Siduan, raja Sipayo, raja Soginti dan raja Bunoyo dipimpin oleg 
sultan muda Biharuddin (putra) dari sultan Sahibullah dari Tamalate Tomini. (SR. Nur, 1979 : 21) Mereka tersebut disamping seorang raja juga bertindak sebegai muballig yang akan membantu penyiaran Islam di kerajaan Gorontalo.

Para raja tersebut diutus mendampingi raja Sultan Amai karena mereka memiliki professional tertentu, yaitu a) Raja Tamalate, Siendeng dan Hulangata ahli dalam masalah hadat kerajaan dan pembuatan peralatan, antara lain seperti tolu, tutup saji dan membuat garam dapur, b) Raja Siduan, Sipayo, Soginti dan Bunuyo menjadi guru dalam masalah yang berhubungan dengan perdukunan dan mantra-mantra. (T.A.Giu, $2002: 3$ )

Dua pendapat tentang masuk Islam di Gorontalo, yaitu a) pada tahun 931 $\mathrm{H} / 1524 \mathrm{M}$, b) tahun $899 \mathrm{H} / 1495 \mathrm{M}$, pendapat kedua (b) yang diperpegangi berbagai pihak karena data tersebut tertulis pada pintu gerbang masuk di masj id Hunto Sultan Amai yang terdapat di kelurahan Biawu Kota Gorontalo. Perjalanan kembali ke kerajaan Gorontalo merupakan ekspedisi bahari dan setibanya dipelabuhan Gorontalo pada tahun 899H/1495 M, mereka disambut oleh masyarakat kerajaan Gorontalo dengan antosias dan penuh terharu, kemudian raja Amai bersama rombongannya melanjutkan ke Biawu yang meruapakan perkampungan Raja Ilohundonga, lokasi yang sekarang dikenal dengan nama Hunto dan terletak dikelurahan Biawu kecamatan Kota Selatan Kota Gorontalo.

Di pumukiman Raja Amai dan permaisuri, rombongan melaksanakan dua kegiatan sebagai media pertama dan utama dalam memperkenalkan Islam pada rakyat Gorontalo, kegiatan tersebut a) bertepatan dengan tiba waktu Dzuhur mereka melakukan shalat Dzuhur di tempat terbuka dan mendapat perhatian masyarakat sekitar, b) pada hari Senin 899 H/1495 M, mereka membangun suatu tempat ibadah (masj id) atau tihi sederhana karena tiga hari kedepan pelaksanaan shalat Jum'at tiba. (Agin, 2002 : 5) Masjid ini diberi nama masjid Hunto sesuai nama tempat pemukiman mereka dan menjadi masjid pertama dan tertua di Gorontalo dan akhirnya masjid Hunto ditambah namanya menjadi Masjid Hunto Sultan Amai untuk mengabdikan nama raja yang pertama menerima Islam, muballig pertama dan pendiri masjid tersebut.

Sejak saat itu raja Amai melaksanakan amanah dengan memaklumkan pada masyarakat Gorotalo, bahwa dia telah menganut Islam sebagai agama, oleh karena itu baginda sultan mengharapkan kepada masyarakat mengikuti jejaknya menganut Islam sehingga Raja Amai digelar ta loo pamaklumu dan pada saat itu pula digelar tulutani (sultan), yautu raja Islam pertama di kerajaan Gorontalo. 
Perlu dikemukakan bahwa setelah Sultah Amai mantap dalam pemerintahannya dan Islam di kesultanan Gorontalo mengalami perkembangan maka Biharuddin dinobatkan menjadi Sultan di kerajaan Tamalate Gorontalo dan pada tahun 931 H/1525 M, Sultan Amai mengharapakan kepada Sultan Biharuddin untuk membangun masjid di kerajaan Tamalate Gorontalo di samping masjid yang berada di Kesultanan Gorontalo dan masjid ini disebut tihi loalipu (masjid kerajaan).

Kedua masjid tersebut dijadikan sebagai sentrum penyebaran Islam dan difungsikan sebagai masjid kesultanan bagi kesultanan Tamalate dan kesultanan Gorontalo dan dari kedua tihi ini digemakan syi'ar Islam di kedua kesultanan yang dilakukan oleh Sultan Amai, Sultan Biharuddin dengan dibantu oleh sultan lain seperti Sultan Siandang dan sulatan Ihulangata. Dalam kurun waktu yang tidak lama raja dan pembesar negeri menganut Islam sebagai agamanya, seperti raja Suwawa, Limboto, Bulingo, Atinggala dan raja Bualemo.

Sultan Biharuddin yang semula mendapat amanah untuk merancang kultur di kesultanan Gorontalo berhasil melaksanakan tugasnya memadukan antara kultur masyarakat kesultanan Gorontalo dengan syari'at Islam, sehingga berhasil menetapkan 188 sendi adat sebagai pedoman dalam kultur Gorontalo yang dipadukan dengan sara'. Keberhasilan ini atas dukungan raja Limboto, Sumawa, Dolango, Atangala, Bualemo dan raja yang berasal dari Kerajaan Tamalate Tomini.

Di masa pemerintahannya Sultan Amai, permaisuri dan putrinya lebih banyak tringgal dikerajaan Tamalate Gorontalo yang diperintah oleh Sultan Biharuddin, oleh sebab itu masa kecil putrinya dihabiskan bersama putri Muharifah (putri Sultan Biharuddin) kerena mereka sebaya, mereka sama-sama memperoleh pendidikan Islam secara ketat di Istana kesultanan Tamalate Gorontalo. Sultan Tamalate Gorontalo memiliki dua istana ksesultanan yang berhadapan di sebalah Timur dan Selatan Masjid Kesultanan, tetapi keberadaan kedua istana dan masjid ini tinggalfoklor karenatelah dihancurkan oleh Kolonial Belanda.

Pada akhir masa pemerintahannya Sultan Amai mengalami krisis rumah tangga yang mengakibatkan permaisuri Owutango meninggalkan istana kesulanan Gorontalo kembali ke-Kerajaan tamalate Tomini meninggalkan Baginda Sultan Amai dan putrinya. Permaisuri berangkat hanya dikawal oleh empat raja yang berasal dari kerajaan Tamalate Tomini (raja Sipayo, Bunuyo, Soginti dan raja Siduan), namun ke-empat raja ini tidak sempat bersama sampai di Tamalate Tomini, tetapi singgah dan tinggal di Bumbar (Pohuato) dan 


\section{Sirajuddin Ismail}

bergelar alongia ( empat raja) bersaudara. Ketika Sultan Amai mangkat maka digantikan atau naik tahta putrinya Matolodulakiki pada tahun $1550 \mathrm{M}$ dan pada masa pemerintahannya Baginda Sultan Ratu melanjutkan sistem pemerintahan yang dilakukan oleh ayah handanya dan pada masa pemerintahannya Islam berkembang dengan pesat karena baginda ratu selalu memotivasi perkembangan Islam di kerajaannya sehingga baginda sultan juga di gelar dengan talopoloopo Islam.

Bersamaan dengan masa pemerinthan sultan Ratu Matolodulakiki, Sultan Sahibullah di Tamalate Tomini (ayahanda) dari sultan muda Biharuddin mangkat, maka Sultan Biharuddin pulang kampung (Tamalate Tomini) dan naik tahta menggantikan ayahandanya (Sahibullah), sedangkan yang membantu menjadi naib di Kesultanan Tamalate Gorontalo, adalah raja muda Pangoliu. Perlu dikemukakan, bahwa pada masa pemerintahan Sultan Biharuddin pusat pemerintahan kerajaan Tamalate Tomini dipindahkan dari Palasa ke-Tamalate Gorontalo atas persetujuan dari Sultan Gorontalo, raja Limboto, Sowawa, Bulango dan raja Bualemo. Demikian pula pada masa pemerintahan banginda Sultan Ratu Matolodulakiki pusat kerejaan Gorontalo juga dipindahkan di kerajaan Gorontalo dan penyatuan kedua pusat kerajaan ini berlangsung hingga pada masa pemerintahan Sultan Jogugu Ejato.

Dalam dinamika historis kesultanan Gorontalo silih berganti pemerintahan (kesultanan) karena raja mangkat. Setelah baginda Sultan Ratu Matolodulakiki mangkat dan digantikan oleh putranya Pangoliu Dai (Pangoliu pertama) dan pada tahun $1585 \mathrm{M}$, sistem pemerintahannya sama dengan kakek dan ayahnya, pada masa ini Islam semakin berkembang dan mewajibkan penganut Islam melakukan sunatan missal bagi anak dan pemuda yang belum disunat dan pembaeatan bagi perempuan yang memasuki usia gadis dengan suatu upacara adat dan mandi lemon dilaksanakan dimasjid Kesultanan Tamalate Gorontalo bertepatan dengan 2 Muharram 1009 H/1611 M, sehingga sultan digelar tato powajibu (orang yang mewajibkan).

Perlu dikemukakan, bahwa pada setiap 1 sampai dengan 10 Muharram di masjid Kesultanan Tamalate Gorontalo sultan melakukan acara silaturrahmi dengan raja Limboto, Sowawu, Bolango, Atinggala dan Bualemo dan dihadiri oleh para pembesar kesultanan/kerajaan, ulama, sara' dan pada acara ini juga dibicarakan berbagai masalah yang berhubungan dengan masalah kerajaan (dunia dan akhirat). (lihat Yassin : 25) Oleh sebab itu masijid memiliki multi fungsi seperti yangterjadi padaawal pengembangan Islam karena di masjid diselesaikan 
segala masalah, antara lain seperti masalah politik dan masalah sosial, disamping yang berhubungan dengan masalah di balik alam nyata karena Islam menuntun umatnya menyeimbangkan antara kepentingan dunia dan kepentingan akhirat.

Sultan Pangoliu digantikan oleh putrinya Moliye (1615 M), kemudian pada tahun 1646 M digantikan oleh suaminya Jogugu Eyato dan pada pemerintahannya kesultanan Gorontalo juga mengalami perkembangan pesat. Masyarakat Gorontalo diwaj ibkan menganut Islam dan baginda Sultan memproklamirkan Islam sebagai agama kesultan Gorontalo sehingga sultan Jogugu Eyato digelar talopatatapu (yang menetapkan Islam sebagai agama negeri) dan baginda sultan Jogugu Eyato adalah sultan pejuang menentang penjajahan Belanda sehingga Baginda Sultan dibuang di Sailan.

Para penyebar Islam pada Kesultanan Gorontalo menggunakan metode yang digunakan oleh Al-Qur'an, yaitu pada awalnya disesuaikan dengan situasi dan kondisi masyarakat sasaran. Para muballig menggunakan mendekatan adaptatif, yaitu kebijakan Sultan Amai awalnya menggunakan metode menyesuaikan dengan adat dengan mengacu pada prinsip saraa topa-topango toadati (sara' bertumpu pada adat). Prinsip dimaksud adalah hukum atau Syari'at bisa berlaku apabila disesuaikan dengan kultur yang berlaku dalam masyarakat. Penggunaan pendekatan seperti ini dengan harapan bahwa Islam diterima oleh seluruh rakyat Gorontalo dan pada akhirnya Islam dijadikan sebagai agama kerajaan.

Kerangka tersebut menunjukan, bahwa Islam masuk di Gorntalo melalui kawin mawin antara seorang raja dengan putri raja atau sebaliknya, oleh sebab itu agama masuk di Gorontalo mulai dari atas (raja) sehingga Islam di Gorontalo berkembang dengan cepat karena ada prinsip masyarakat di suatu kerajaan, bahwa hidup dan kehidupannya adalah milik raja, titah raja adalah suatu kewajiban, oleh sebab itu menganut Islam bagi masyarakat Gorontalo adalah suatu kewaj iban yang harus dipatuhi dan berlanjut hingga saat ini, rakyat Gorontalo menjadi Muslim yang ideal, bukan orang asli Gorontalo kalau tidak Islam. Proses ini memiliki persamaan dengan proses Islamisasi di kerajaan Gowa dan Tallo (Sulawesi Selatan), yaitu Islamisasi dimulai dari atas (raja).

Proses Islamisasi di suatu daerali berbeda sesuai dengan situasi dan kondisi masyarakat sasaran. Mereka menggunkan pendekatan Islamisasi sesuai dengan kondisi masyarakat agar mereka mudah menerima seruan tersebut, maka tidak heran kalau Raja Muda Biharuddin pada awal kegiatan da'wahnya mencanangkan prinsip sara' bersendikan adat, setelah ke-Islam-an masyarakat telah kuat dan seluruh masyarakat kerajaan Gorontalo menganut 
Islam maka Sultan Gorontalo memproklamirkan prinsip adat bersendikan sara' dan sara' bersendikan Kitabullah. Kerangka tersebut menunjukan, bahwa tiga orang Sultan pada kesultanan Gorontalo yang sangat berjasa dalam Islamisasi dan pengembangan Islam di kerajaan Gorontalo, yaitu Sultan Amai, Sultan Matolodulakiki (Ratu Sultan) dan Sultan Jogugu Eyato.

\section{Peran Sultan Amai}

Sultan Amai memerintah pada 1532 - 1550 M, kalau dilihat proses awal Islamisasi meletakan Sultan Amai a) seorang yang pertama menerima dinul Islam, b) seorang raja yang membawa dan mengembangkan Islam (muballig) di kerajaan Gorontalo, c) menjadikan kerajaan Gorontalo menjadi kerajaan Islam, d) wajar kalau disebut raja yang pertama disebut Sultan di kerajaan Islam Goronalo.

Dalam mensosialisasikan Islam di kerajaan Gorontalo Sultan Amai bersama rombongannya yang berasal dari Palasa kerajaan Tamalate Tomini melakukan kegiatan, yaitu 1) melaksanakan shalat Dzuhur pertama di pemukimannya di Hunto, 2) mendirikan Masjid Hunto yang akhirnya dinamakan masjid Hunto Sultan Amai. Kerangka tersebut menunjukan, bahwa seharusnya masjid Hunto Sultan Amai dijadikan pusat pendidikan dan pengembangan Islam, artinya pusat kegiatan pemahaman dan pendalam ilmu Islam karena hal ini merupakan hal yang mendasar dalam ajaran Islam, iman, amai (ilmu) dan menjadi sumber utama kultur dan peradaban orang Islam pada masa pemerintahan Sultan Amai.

Pada dinamika pengembangan peradaban Islam Sultan Amai menggunakan pendekatan adaptatif dengan prinsip saraa topa-topanga to adati ('sara' bertumpu pada adat). Pada masa pemerintahannya di dampingi oleh delapan raja dari Palasa berhasil membuat 185 macam pola adat yang merupakan akulturasi kultur masyarakat kerajaan Gorontalo dengan kultur kaum Muslimin yang Islami, antara lain adat perkawinan, penyelenggaraan jenazah, pelaksanaan ibadah, mengatur hubungan sesama (adat dalam pergaulan), pembinaan remaja, kesenian yang bernafaskan Islam, kerukunan antara rakyat dan pemerintah, kerukunan hidup, penghormatan terhadap tamu, sosial, rumah tangga dan pembinaan sosial keagamaan.

Disamping itu Sultan Amai juga menjadikan kesenian sebagai medya pengembangan budaya dan peradaban Islam, antara lain a) kesenian yang berhubungan dengan kematian, yaitu leningo (pantun agama yang berisi nasehat bahwa semua mahluk hidup pasti akan menghadap kematian). Tinilo (pujian 
terhadap para leluhur dilantungkan untuk mengiringi pengantaran batu nisannya ke kubur). Hantalo (gendering yang dibunyikan menjemput tamu pada upacara pemakaman seorang pejabat negeri (bubato). b) kesenian yang berhubungan dengan peringatan maulid Nabi Muhamad SAW, yaitu berupa dikili (zikir) tentang kelahiran Nabi, c) kesenian yang berhubungan dengan perkawinan, antara lain mohatamo Quruani (chatam Qur'an) dilakukan pada malam walimatur urusy (pesta perkawinan).

\section{Sara' yang Diadatkan}

Sara' yang di adatkan, yaitu perintah mengikuti syari'at Islam hanya sosialisasinya melalui adat yang tidak bertentangan dengan tujuan syari'at, antara lain 1) pelaksanaan ibadah shalat mengacu pada hadis Ibnu Mas 'ud, yaitu hendakalah orang yang sudah balig dan pandai di antara kamu di dekatku. (Hadis) maksudnya orang yang sudah balig dan berilmu berada pada shaf yang terdepan, oleh sebab itu adat menetapkan bahwa shaf terdepan di masjid ditempati oleh pejabat negeri (utamanya di daerah), 2) hadis Bukhari Muslim, apabila tiba waktu shalat maka hendaklah adzan salah seorang di antara kamu. (Hadis) maksudnya adalah panggilan untuk melaksanakan shalat, adat Gorontalo menetapkan untuk pejabat utama di daerah yang malaksanakan shalat Jum'at atau shalat Id akan dijemput oleh tokoh adat dengan cara mohama wombato (menjemput tikar shalat) dan hal ini berlaku pula pada peminangan dalam suatu perkawinan.

\section{Adat yang di-Islamkan}

Adat yang di Islamkan, artinya yang dimaksud pelaksanaan berdasarkan adat, tetapi secara konteks adalah Island, antara lain pada acara belasungkawa, a) mapodidi, mengandung makna yang Island. Didi, adalah simbol ta 'ziah dan langsung memohonkan magfirah bagi almarhum dengan berzikir (zikir qalbu), b) memandikan zenazah, air yang disiramkan yang terakhir disebut taluhu liduyo, air yang berwarna putih, kuning dan merah darah. Air merah untuk menyiram mulai dari kepala hingga kaki dan berakhir di pusat. Warna merah untuk mensucikan sifat amarah. Warna kuning simbol harapan untuk mensucikan perbuatan kotor yang bersumber dari qalbu. Sedangkan warna putih, adalah air untuk siram terakhir, sebagai simbl harapan agar segala dosanya diampuni (terhapus).

Pada masa pemerintahan Motolodulakiki telah melahirkan dua tokoh dalam masyarakat Gorontalo, yaitu tokoh agama (ulama) dan tokoh adat. Tokoh ini yang berperan dalam pembangunan budaya dan peradaban Islam di Gorontalo. Pikiran Sultan sangat mendasar dan berlian karena Islam menjadi pegangan 
utama dan pedoman hidup, baik oleh pembesar kerajaan maupun oleh masyarakat dan sikap seperti ini cenderung pada usaha menjadikan Islam sebagai agama kerajaan Gorontalo.

\section{Peran Sultan Matolodulakiki}

Sultan Matolodulakiki, adalah putri dari Sultan Amai (1550 - 1585), pola pemerintahan dan kepedulian terhadap Islamisasi di kerajaan Gorontalo sama dengan baginda ayahandanya (Sultan Amai), hanya Matolodulakiki melakukan terobosan di dalam pengembangan kultur masyarakat Gorontalo. Pengembangan peradaban Islam dari pendekatan adaptatif dengan mengembangkan menjadi akulturasi budaya dengan sistem adati hula-hula to saraa, saraa hula-hula to adaptii (adat bersendi pada sara', sara' bersendikan kitabullah). (S.R Nur, 1979 : 221) sistem ini mendekatkan masyarakat pada Islam dan memudahkan penerimaan sehingga dalam perkembangannya Islam memiliki dampak, yaitu a) adat bersendikan pada sara' melahirkan adat yang Islami, b) sara' bersendikan adat, melahirkan Islam yang di adatkan.

\section{Peran Sultan Jogugu Eyato}

Sultan Jogugu Eyato sebelum dinobatkan menjadi sultan, baginda dikenal sebagai khatib besar, seorang sufi yang diketahui sangat mengutamakan kesucan bathin. (Polontalo, 1998 : 67) Sultan ni adalah sultan ke enam pada struktur kerajaan Gorontalo bagian utara, tetapi dalam struktur kerajaan Gorontalo Islam (kesultanan) adalah sultan yang ke lima. Rentang waktu antara pemerintahan sultan Motolodulakiki dengan sultan Jogugu Eyato di selingi oleh dua orang raja selama kurun waktu 88 tahun.

Pada pemerintahan kedua orang raja (pengantara) ini agama Islam statis bahkan cenderung mundur karena masyarakat hanya mengutamakan kultur asli masyarakat Gorontalo dan mengenyampingkan kultur yang Islami. Kondisi seperti ini yang memotivasi sultan Jogugu Eyato mencetus pranata Islami yang lebih idial dari sistem yang diberlakukan oleh Sultan Amai dan Sultan Motolodulakiki untuk menghadapi kemunafikan masyarakat tentang roh Islam (tauhid). Pranata sebagai sistem pantang surut menghadapi kemunafikan tersebut, adalah adati hula-hulaa to saraa, saraa hula-hulaa to Quruani (adat bersendikan sara', sara' bersendikan kitabullah).

Beradasarkan sisten ini Sultan Jogugu Eyato dengan Arif melakukan perubahan, antara lain : 
1). Meminta pada bantayo po boide menambah kalimat pidato penobatannya sebagai Sultan, dari kalimat yang biasa dipidatokan sebelumnya, yaitu kalimat dila poluliya lo ito eya (tetapi tuanku tidak diperbolehkan menyalahgunakannya).

Kalimat pidato penobatan raja sebelumnya, yaitu:

- Huta- huta lo ito eya ftanah, adalah kepunyaan tuanku).

- Taluhu- taluhu lo ito eya (air, adalah air kepunyaan tuanku).

- Duputo-duputo lo ito eya (angin, adalah angin kepunyaan tuanku).

- Tawu-tawu lo ito eya (manusia adalah manusia kepunyaan tuanku)

Tambahannya: dila poluliya lo ito eya (tetapi tuanku tidak diperbolehkan menyalahgunakannya).

Pada upacara penobatan Sultan Jogugu Eyato diwarnai dengan makna yang menyangkut tugas berat dan mulia, antara lain dapat dilihat pada kalimat:

a). Tugas Maharaja; moiyo to Allah ... walo Mursala loo wall oe sagala fmembantu Allah dan nabi utusanNya, yang telah menciptakan segalagalanya).

b). Usaha memakmurkan rakyat, berpedoman pada; agama to taluu, lipu pei hulaluu (agama menjadi patokanku dalam mengendalikan negeri ini).

c). Penyelenggaraan pemerintahan, dasarnya; oliide olimbunga oladia poheluma (ada aturan pemerintahan yang di dampingi oleh dewan permusyawaratan).

2). Pembatasan kekuasaan raja. Sultan Jogugu Eyato merumuskan, bahwa kekuasaan yang pada diri manusia, terbagi atas kekuasaan lahir dan kekuasaan bathin. Untuk menghindari mabuk kekuasaan duniawi maka satu-satunya adalah menyandarkan kekuasaan itu pada kehendak Allah SWT, sehingga bathin akan disinari oleh cahaya Islam. Rumusan kekuasaan yang ditetapkan oleh sultan Jogugu Eyato yang didampingi oleh Bantayo po boida, menetapkan pensyaratan seorang yang dipilih menjadi khalifah atau maharaja, adalah a) bijaksana, pintar, berpendirian teguh, b) beragama dan berakhlak mulia, c) pengendalian diri dan bijaksana dalamkekuasaan, d) kasih saying kepada rakyat, e) adil, f) berani dan bijak di dalam menghadapi tantangan.

3). Sistem pemerintahan berdasarkan aqidah Islam dan mewajibkan sebagian sifat 20 Allah SWT mejadi acuan semua aparat kerajaan mulai dari pejabat rendahan sampai pada pejabat tinggi, antara lain a) sifat nafsiah, sifat 
kepribadian atau sifat wujud (ada). Sifat ini diwujudkan bahwa kerajaan itu ada karena ada aktivitas para pejabat dan aktifitas itu harus sesuai tuntunan Allah SWT dan Rasul SAW, b) mukhalafatuhu HI hawadis, sifat berlainan dengan mahluk yang ditujukan pada perbedaan antara rakyat dan pejabat, maka kalau pejabat melanggar hukum maka hukumannya lebih berat dari hukuman yang diberlakukan pada masyarakat, c) qalam, berbicara yang benar diperuntukan pada buntayo poloide, artinya mereka harus berbicara yang benar, musyawarah dengan niat untuk kepentingan rakyat dan kerajaan, d) wahadahiyah (Esa), ditujukan pada kerajaan, persatuan seluruh rakyat, pembesar kerajaan dan seluruh alam merupakan hubungan zimbiotik, e) sama, basar (mendengar, melihat) diperuntukan pada walaupulu (kepala kampung) untuk mendengar keluhan rakyat dan wajib menyampaikan pada atasannya dan sebaliknya, f) qidam (lebih dahulu), siap sedia diperuntukan pada keamanan agar siap dan taat dalam melaksanakan tugas, g) qiamu binafsihi (berdiri sendiri) ditujukan kepada baate, wиu, mereka harus tegas pada prinsip tanpa dipengaruhi oleh yang lainnya, h) $b a q a^{\prime}$ (kekal) sifat yang harus dimiliki oleh sara', qadi, mufti, imam dan saradaa, mereka melaksanakan syari'at Islam secara kaffah tanpa dipengaruhi oleh aliran apapun.

4). Pembinaan Islam. Sistem pemerintahan sultan Jogugu Eyato mempertahankan ketiga sistem pemerintahan, salah satu diantaranya adalah menempatkan qadi pada bagian formal. Tugasnya membina Islam, menasehati sultan, mengetuai pengadilan pidana dan perdata. Disamping itu tugas utama qadi, adalah a) membina Islam, b) membangun masjid dengan wakaf, c) menyelenggarakan perayaan Islam baik di istana maupun di masjid, d) membina peradilan, e) menjadi penasehat pada siding kerajaan dan peradilan dalam hukum Islam. (Polontalo, 2002 : 20) Sedangkan dalam menjalankan tugasnya qadi dibantu oleh; a) moputi atau mufti (penasehat di bidang agama Islam), b) panthongo (penasehat tentang ilmu falak), c) imam (memimpin ibadah), d) saradaa (wakil imam, pengatur tata tertib peribadatan, e) lebi (pembantu saradaa), f) kasisi (anggota pembantu saradaa). (Ina Moo, $1979: 25$ )

5). Memperhatikan iptek dan imtak. Dasar pemikiran sultan Jogugu Eyato . melaksanakan imtek dan imtak, bahwaAllah SWT memiliki sifat maani yang salah satu sifat itu adalah ilmu, Allah mengetahui dan hal ini di jadikan acuan pantas atau tidaknya seseorang menjadi raja, antara lain bijaksana, cendekia, adil, memiliki akhlak mulia dan hal ini berlaku pula bagi pembesar kerajaan.

Mengacu pada keriteria tersebut maka kemampuan pembesar kerajaan dikelompokan atas empat (4) bagian, a) kelompok kekuasaan yang menangani 
keamanan dan keuangan, b) kelompok kehidupan, menangani pertanian dan petemakan, c) kelompok cendekiawan, menangani kehidupan keagamaan dan adat, d) kelompok kesenangan, menangani pembangunan fisik, antara lain seperti jalan, pengairan, perindusterian dan gedung.

Perlu dikemukakan, bahwa keempat pembagian kerja tersebut memerlukan ilmu pengetahuan tentang sifat Allah SWT, yaitu qudrat, iradat, ilmu dan hayat dan sifat ini diperuntukan bagi pemangku jabatan, a) qudrat (kuasa) harus dimiliki oleh pejabat di bidang kekuasaan dilambangkan dengan warna merah sebagai simbol kemampuan, bahwa pejabat tersebut haru memiliki kemampuan menghadapi segala sesuatu, b) iradat (kemauan) harus dimiliki oleh pejabat yang menagani kehidupan, dilambangkan dengan warna kuning, sebagai simbol kemauan untuk mensejahterakan masyarakat, c) ilmu (pengetahuan) harus dimiliki oleh pejabat yang menjabat bidang ilmu pengetahuan dan pendidikan dengan lambang warna kuning, sebagai simbol kedewasaan, d) hayat (hidup) harus dimiliki oleh pejabat yang menjabat bidang kesenangan, ekonomi dengan lambang hijau sebagai simbol kesuburan, pembangunan bidang ekonomi. (Liputo, 1945 :14)

Kerangka tersebut menunjukan, bahwa ketiga sultan ini yang berperan dan sukses dalam proses Islamisasi dan mengantar Islam pada masa pengembangan dan keemasan Islam di kerajaan Gorontalo dan dalam masa pemerintahannya ketiga baginda sultan memadukan antara adat dan sara' sehingga Islam mudah diterima dan berkembang dalam kehidupan masyarakat Gorontalo, sehingga ketiga baginda sultan dikenal dan terkenal dalam kehidupan masyarakat Islam Goronalo, terutama Sultan Amai karena seandainya baginda Sultan Amai tidak ada maka kemungkinan Islam dipertanyakan berada di bumi persada (kerajaan) Gorontalo. Sejak itu Islam berkembang dengan pesat hingga dewasa ini, oleh karena itu berkembang suatu istilah dalam dalam masyarakat Gorontalo, bahwa bukan orang Gorontalo kalau dia tidak menganut Islam.

\section{E. Penutup}

Masuknya Islam di berbagai daerah terkait dengan masuk Islam di Nusantara (Indonesia) pada abad pertama Hijriah dan sampai di Sulawesi melalui kontak perdagangan antar saudagar, maka tidak mengherankan orang yang pertama menerima Islam pada umumnya orang yang berada di daerah pantai atau di Bandar-bandar yang merupakan jalur perdagangan dan sampai di kerajaan Tamalate Tomini yang terletak di Teluk Tomini yang merupakan jalur masuknya Islam di Gorontalo, hanya masuk Islam di kerajaan Gorontalo bukan melalui kontak perdagangan tetapi melalui kawin mawin antara raja Gorontalo (Amai) dengan Putri Awutonga putri raja Boneneto (raja Tamalate Tomini). 
Orang yang pertama menerima Islam di Gorontalo adalah Raja Amai, menerima Islam langsung di Palasa kerajaan Tamalate Tomini dan Baginda Sultan Amai yang membawa dan menyebarkan Islam di kerajaan Gorontalo dan setelah di Gorontalo baginda digelar Sultan Amai dan dikenal dalam masyarakat sebagai seorang raja yang pertama menerima, muballig (penyebar Islam) pertama di Gorontalo di bantu oleh enam raja lokal yang berasal dari kerajaan Tamalate Tomini yang dipimpin oleh Putra Mahakota Biharuddin.

Sejak masa pemerintahan Sultan Amai hingga masa pemeritahan Matalodulakiki menggunakan azas dan pendekatan adaptatif, yaitu sara' berdasarkan adatt. Sedangkan Sultan Jogugu Eyato juga memerintah dengan memadukan antara sara' dengan adat seperti sultan yang lain, tetapi baginda Sultan Jogugu Eyato menyepurnakan azas kerajaan menjadi adat bersendikan sara' dan sara' bersendikan Kitabullah karena Sultan menganggap bahwa pemerintahan dan rakyatnya telah matang untuk memberlakukan azas seperti itu dan sistem perpaduan antara sara' dan adat dalam kehidupan masyarakat Gorontalo tetap berlaku hingga kini.

\section{DAFTARPUSTAKA}

Abdullah Puar, Masuknya Islam Ke Indonesia, Cet. Kedua, Cet. Kedua, CV. Indradjaja, Jakarta, 1984.

Ina Moo, Sejarah 23 Januari 1942 di Gorontalo, Yayasan 23 Januari, Jakarta, 1942.

Liputo M, Sejarah Gorontalo IV, Percetakan Rakyat, Gorontalo, 1943.

Muin Umar dalam Hj. Sri Banun Muslim, Islam Di Pulau Lombok, kajian Historis Tentang Perkembangan Islam di Lombok, Stain Negeri Mataram, Mataram, 1999

Jas Pers dalam Hj. Sri Banun Muslim, Islam di pulau Lombok, Kajian Historis Tentang Perkembangan Islam di Lombok, STAIN Mataram, mataram, 1999.

Polontalo, Ibrahim, Peranan Tidi Lo Polopala Gorontalo Dalam Pembinaan Kepribadian Suku Gorontalo, FKIPIKIP Manado, Manado, 1968.

sejarah Perkembangan Islam Sebagai Sumber Budaya Dan Paradaban pada Kerajaan Gorontalo Sejak Abad Ke XVI, fmakalah), Gorontalo, 2002.

SR. Nur, Liam Pohalaa, Susunan Sara'Hukum Adat Dan Kebijaksanaan Pemerintah di Gorontalo (BJHaga), Jambatan, Jakarta, 1981

Juahaerini dalam Hj. Sribanun Muslim, Islam Di Pulau Lombok, Kajian Historis Tentang Perkembangan Islam di Lombok, STAIN Mataram, Mataram, 1999. 